\title{
ANALYSIS OF THE EFFECT OF PRODUCTION, PROMOTION AND DISTRIBUTION COSTS TOWARDS COMPANY'S SALES OF THE FAST MOVING CONSUMER GOODS SECTOR
}

\author{
Hapsari Winahyu*, Sumarwan Ujang, Wijayanto Hari \\ School of Business, Bogor Agricultural Institute, Indonesia \\ *E-mail: winahyu.hapsari@gmail.com
}

\begin{abstract}
The purpose of this study is to analyze the influence of production costs, promotion costs, and distribution costs partially on the value of sales and analyze the influence of production costs, promotion costs, and distribution costs together on the value of sales. Consumer goods companies are closely related to the increasing consumption of society. The sector involves a large amount of labor compared to other industries. Therefore, cost control is needed by the company to regulate the availability of funds so that it is sufficient to finance operational activities. The sampling method in this study was purposive sampling or judgment sampling. The research data are panel data consisting of time series data and cross section. The time series data used is company data for 2012-2016. The cross section data consists of 23 consumer goods sector companies listed on the Indonesia Stock Exchange. There are four variables in this study, namely the independent variable consists of variable production costs, promotion costs, and distribution costs, while the dependent variable is the sales variable. Processing and technical data analysis in this study is descriptive statistical analysis, panel data, and model suitability tests using SPSS and Eviews software. Based on the results of the analysis using the panel data regression equation the results of the best method are obtained by the Fixed Effect Model. Based on the results of the analysis using a fixed effect model, the consumer goods company promotion and distribution variables have a significant influence on the value of sales. The company must have a supervision and quality control department that works in every production process. In the consumer goods sector companies that are directly related to consumers, they can directly carry out promotions through advertisements in electronic media and print media. The increasing growth of internet users can also be an opportunity for marketing channels. By utilizing the internet, companies can create e-commerce platforms to reach wider consumers.
\end{abstract}

\section{KEY WORDS}

Production costs, promotion costs, distribution costs, company's sales.

Companies are required to be able to seize the market and compete with other companies, so that each company must be able to develop appropriate management activities. Companies need to pay attention to what consumers need and want to be able to improve product quality, provide facilities that are beneficial to consumers and increase consumer confidence in the quality provided by the company (Wardhani 2015).

One of the activities carried out by a company is to compile a budget. Costs become a very important part of the company; one of the most important cost components is production costs, promotion costs and distribution costs. These costs are factors that influence the determination of selling prices. Production costs are costs associated with transforming raw materials into a product (World 2018). Raw materials are closely related to the amount of production costs incurred, the increase in production can be done by increasing good industrial raw materials. Production cost efficiency and high profit margins can be obtained from the acquisition of cheaper raw materials. (Fachrodji 2009). This fee is related to determining the selling price of the product based on the cost of production. Pricing is also included in the marketing strategy, namely by setting competitive prices and adjusting prices with the benefits obtained (Marwa 2014). 
Promotional costs are costs sacrificed or issued by the company in carrying out marketing activities. The total promotional costs are the sum of all costs incurred by the company when the company promotes various kinds of promotional tools, such as advertisements, and exhibitions (Rustami et al. 2014). Advertising that is persuasive (persuasive advertising) by advertising the advantages ranging from benefits, saving time, costs, and practicality to be obtained (Heviandri 2009). Repeated ad impressions are expected to increase purchasing power of products offered by producers (Sumarwan 2012). In other studies, repeated advertisements cause consumers to get bored and can react negatively to advertisements (Sumarwan 2011). One of the goals of advertising is to become a top of mind product. Top of mind describes the brand that is first remembered by consumers or is first called when asked about a product (Sumarwan 2010). Marketing activities can also be done with education and training, improving the quality of product distinctiveness, and product diversification (Savitri 2014).

Promotions also need to be supported by good product distribution or distribution. According to Ardiyos (2008) distribution costs are costs for warehousing, transportation, packing, exporting facilities to put into crates. The distribution channel or often referred to as the marketing channel is a path that must be passed by the flow of goods from the producer to the intermediary to the consumer. To support the affordability of product access, it is necessary to select retailers who are closer to consumers and require marketers to sell directly to consumers (Oktoriyana 2014). Timely distribution or shipping is one guarantee of customer satisfaction (Manalu 2007). Therefore, the selection and use of an effective distribution channel is needed so that the delivery of goods can be done easily and quickly. The chosen distribution channel will then influence the decision on the selling price of a product. (Munawar 2008).

Distribution channels are used by companies to determine how and where consumers will make the purchase process. Purchasing is the final goal of the stage of need recognition, alternative information seeking and evaluation. In carrying out the purchasing process, consumers make decisions about the brand, place of purchase, consideration in choosing the place, place of purchase, consideration in choosing the place, and how consumers decide on purchases (Sumarwan 2013).

The final result of the achievement of a company from the sale of the product produced is called the company's sales. The company's sales are achievement expressed quantitatively in terms of physical or volume or unit of a product. The value of sales and cost control are important factors in the company which can also affect company profits.

Sari (2015) in his research entitled The Effect of Promotion Costs and Distribution Costs on Sales (Study of Food and Beverage Sector Companies Listed on the Indonesia Stock Exchange for the Period 2009-2013). The results of the study stated that promotion costs and distribution costs simultaneously had a significant influence on sales. Partially promotion costs have a significant effect on sales and distribution costs have a significant effect on sales.

According to Wardani (2013) in his thesis which examined the effect of production costs, promotion costs, and distribution costs on company's sales in the consumer goods industry, all variable components free of production costs, promotion costs, and distribution costs proved to significantly affect the company's sales of investment companies. foreign and domestic investment. Based on this background, the purpose of this study is to analyze the effect of production costs, promotion costs, and distribution costs on the sales of consumer goods sector companies listed on the Indonesia Stock Exchange either partially or simultaneously.

\section{LITERATURE REVIEW}

Production is the activity of the company processing and converting raw materials into finished goods. According to Nasution (2003) states that the production process is a method and techniques used in processing raw materials into finished products. Costs associated with making goods and providing services are called production costs (Hansen, Mowen 
2006). The elements of production costs can be grouped into three, namely raw material costs, labor costs, and factory overhead costs.

According to Kotler (2008), marketing is a social and managerial process where individuals and groups obtain what they need and want through the creation and exchange of products and values with other parties. The marketing concept states that the key to creating shareholder value is to build relationships with target consumers based on satisfying their needs more efficiently than competitors (Sumarwan 2009).

The marketing concept states that the key to achieving organizational goals depends on determining the needs and desires of the target market and giving desired satisfaction more effectively and efficiently than those of competitors. Some of the objectives of a marketing system are maximizing consumption, maximizing customer satisfaction, maximizing choices, and maximizing quality of life (Kotler 1994).

Promotion is related to communication activities to influence other people to accept ideas, concepts, and other things. According to Hermawan (2012) promotion is one of the priority components of the activity of telling consumers that the company launches new products that make consumers carry out purchasing activities. The more promotion is carried out, the greater the promotion costs, the greater the promotional costs are incurred, the sales will rise. In promotional activities a company requires costs to increase sales. The promotion costs represent a number of funds that the company disbursed into promotions to increase sales (Simamora 2002).

Promotion can be said as marketing communication, namely communication activities carried out by buyers and sellers and is an activity that helps in decision making in the field of marketing and directs exchanges to be more satisfying by making all parties aware of doing better (Swastha 2008). According to Assauri (2009) promotion is an effort of the seller or producer in informing goods or services to buyers or consumers, so that buyers / consumers are interested in making purchase or exchange transactions for products or services sold or offered

According to Kotler and Keller (2002) distribution channels are a group of companies or individuals who have ownership rights to products or help move ownership rights to products or services when transferred from producers to consumers. Good distribution requires collaboration in the supply chain, namely collaboration from all different activities and the existence of interrelationships in the supply chain. Successful collaboration allows the movement or distribution of goods in a timely manner from suppliers to manufacturers to the final consumer, and allows the company to maintain inventories at low levels and at low prices (Anatan, Elitan 2008).

The functions of the distribution channel according to Kotler and Keller (2002) are:

- Information, which is collecting important information about consumers and competitors to plan and help exchange;

- Promotion, namely the development and dissemination of persuasive communication about the products offered;

- Negotiation, namely trying to agree on prices and other conditions, thus allowing the transfer of ownership rights.

Sales is the interaction between individuals meeting each other face that is intended to create, improve, control or maintain exchange relations so that it is beneficial for others (Swastha 2008). Sales volume is a measure that shows the amount or amount of goods or services sold (Mulyadi 2005). According to Kotler (2008) there are several factors that influence company sales, including:

- Selling price. The selling price factor is related to the affordability of consumers in consuming goods or services offered by the company;

- Products. The product is one of the factors that affect the level of sales volume, as the goods or services offered by the company whether it is in accordance with the level of needs of consumers;

- Promotion Fee. Promotion cost factor is a marketing activity that seeks to disseminate information, influence, persuade, and increase the target market of 
companies and products to be willing to accept, buy, and be loyal to the products offered by the company;

- Distribution Channels. It is a company activity to deliver and distribute goods offered by the company to the consumers they aim for;

- Quality and quality of goods. With good quality, consumers will remain loyal to the products of the company, resulting in repeated purchases that have an impact on increasing the volume of product sales.

\section{METHODS OF RESEARCH}

The sampling method used in this study was a purposive sampling or judgmental sampling method. According to Sugiyono (2010), purposive sampling is a technique of determining research samples with certain considerations aimed at making the data obtained more presentative. The statistical analysis method used is panel data regression method. Panel data is a combination of cross section data and time series data. Cross-section data is data collected in one time against many individuals. While time series data is data collected from time to time on an individual (Nachrowi 2006). The time series data used is annual data for five years, from 2012-2016, while the cross section is consumer goods sector companies listed on the Indonesia Stock Exchange. In this study there were 4 variables studied, namely:

- Production costs (X1). Production costs are costs which consist of direct labor costs, raw and supporting material costs, and company overhead costs;

- Promotion Costs (X2). Promotion costs are costs that consist of sales promotion costs and advertising costs;

- Distribution Costs (X3). Distribution costs are costs that consist of sales costs, shipping costs (transportation) and warehousing costs;

- Company's Sales (Y). Company sales is a measure that shows the amount or amount of goods or services sold.

There are several techniques that can be used to estimate the parameters of the panel data:

- Pooled Least Square. The approach to using this method is the simplest method. In his estimation it is assumed that each individual unit has the same intercept. The panel regression data generated will apply to each individual;

- Fixed Effect Model. In the FEM method, interception in regression can be distinguished between individuals because each individual is considered to have its own characteristics;

- Random Effect Model. The REM method appears when there is no correlation between individual effects and regression. In this model, different parameters between individuals and between times are included in the error. In random effect models, there are two components that contribute to the formation of errors, namely individual and time, so random errors in random effect models also need to be parsed into errors for individual components, time component errors and combined errors.

To determine which best model that can be used, several tests are carried out, namely:

- Chow Test. Chow Test is a statistical test that aims to choose which model is better used between PLS or FEM models;

- Hausman Test. The Hausman test is a test conducted in choosing the use of the FEM or REM model;

- Langrange Multiplier test. The Langrange Multiplier test is a statistical test that aims to choose which model is better used between the REM or PLS models.

In the panel data regression model, it is necessary to fulfill the requirements, which are free from classical assumptions; several tests carried out include data normality test, multicollinearity test, autocorrelation test, and heteroscedasticity test. In addition, it is necessary to conduct a feasibility test to test the regression coefficients which have a significant influence or not. Tests carried out are $\mathrm{F}$ test, $\mathrm{T}$ test, and determination coefficient $\left(R^{2}\right)$. 


\section{RESULTS AND DISCUSSION}

The research data is obtained from the complete financial statements of each company for five years, in 2012, 2013, 2014, 2015, and 2016. Growth in production costs, pharmaceutical sector companies are the companies with the highest growth value. In 2012 the company experienced an increase in production costs by $63.44 \%$. Decreasing production costs was experienced by household appliances sector companies with a decline of up to $26 \%$ in 2013. At promotional costs, the household appliances sector experienced a decline and drastic growth. In 2013 the household appliances sector company decreased by $75.32 \%$ and in 2015 the growth in promotional costs was $44.43 \%$. The highest distribution costs are growth in the pharmaceutical sector companies by $28.5 \%$ while the companies that experience a decrease in distribution costs are companies in the household sector by $57.37 \%$. The growth of sales value from each sector of the company has increased every year except in the household appliances sector. The biggest decline in the household appliances sector was recorded in 2013 , which was $24 \%$ while the increase in the sales value of the largest companies was in the food and beverage sector in 2012 of $18.99 \%$.

Selection of the best model. When compared to the three methods of PLS, FEM, and REM can be seen based on the R-squared value. Obtained the R-squared value of the PLS method of 0.952197 , the FEM method produces an estimate with R-squared of 0.997873 and uses the REM method to get the R-squared result of 0.860689 . When comparing the three PLS, FEM, and REM methods, it can be seen based on the R-squared value, it can be seen that the FEM method gives significant results. The FEM method produces an estimate with R-squared of 0.997873 indicating the compatibility of the model between production costs, promotion costs, and distribution costs for sales. As much as $99.78 \%$ can be explained by variable production costs, promotion costs, and distribution costs, while as much as $0.22 \%$ is explained by other variables outside the model.

Table 1 - Estimation results using the PLS, FEM, and REM methods

\begin{tabular}{lccc}
\hline \multicolumn{1}{c}{ Pooled Least Square } & \multicolumn{2}{c}{ Fixed Effect Model } & Random Effect Model \\
\hline coefficient & & & \\
Production & 0,548979 & 0,254574 & 0,325013 \\
Promotion & 0,275498 & 0,188495 & 0,201800 \\
Distribution & 0,163455 & 0,257387 & 0,263977 \\
Prob & & & \\
Production & 0,0000 & 0,0000 & 0,0000 \\
Promotion & 0,0000 & 0,0000 & 0,0000 \\
Distribution & 0,0000 & 0,0000 & 0,0000 \\
& & & \\
R-squared & 0,952197 & 0,997873 & 0,860689 \\
Adjusted R-square & 0,950905 & 0,997276 & 0,856924 \\
Sum squared resid & 15,24339 & 0,678252 & 1,027565 \\
F-statistic & 737,0084 & 1670,166 & 228,5931 \\
Prob (F-statistic) & 0,000000 & 0,000000 & 0,000000 \\
Durbin-Watson stat & 0,122312 & 1,708065 & 1,199502 \\
\hline
\end{tabular}

Stage evaluation model. The Chow test showed that the F-test and chi-square results were significant. The resulting prob value is smaller than the significance level $\alpha=5 \%(0.0000$ $<0.05)$ this means that the FEM method is better when compared the PLS method with a confidence level of $95 \%$.

Table 2 - Results of the chow test and hausman test

\begin{tabular}{lll}
\hline & Chow test & Hausman test \\
\hline Prob. Cross-Section F & 0,0000 & \\
Prob. Cross-Section Chi-square & 0,0000 & 0,0000 \\
d.f. Cross-Section F & 22,89 & \\
d.f. Cross-Section Chi-square & 22 & 3 \\
Chi-Sq. Statistic & & 26,836775 \\
\hline
\end{tabular}


Then followed by a Hausman test to choose between the FEM and REM methods. In the Hausman test, the prob. value of 0.0000 is smaller than the $5 \%$ level, the best method that must be used is FEM. Based on the chow test and the best Hausman test model for this data is FEM (Fixed Effect Model).

Classical test assumptions. Normality test was carried out by Jarque Bera test. The panel data estimation results show a probability value of 0.243843 greater than the significance level value of $5 \%$. So it can be concluded that the residuals distributed normally. In the test of Durbin Watson autocorrelation of 1.708065 between $\mathrm{dL}$ and 4-dU, there is no autocorrelation on the model. In heteroscedasticity test, it can be said that there is no problem of heteroscedasticity because the value of the sum squared resid weighted $(0.659099)$ is smaller than the sum squared resid unweighted (0.700960). Multicollinearity test can be seen from the value of the correlation matrix between variables. From the correlation matrix, it can be seen that the correlation between production costs and distribution costs is quite high, but smaller than the R-squared value of $99.78 \%$, so it can be concluded that there are no multicollinearity between independent variables. The coefficient of determination $\left(R^{2}\right)$ Based on the results of the FEM model, the R-Squared value is $99.78 \%$, which means that $99.78 \%$ diversity $Y$ can be explained by the independent variable $(\mathrm{X})$ used while the remaining $0.22 \%$ is explained by factors others outside the model.

Goodness of fit panel data regression model. The $\mathrm{F}$ test is used to test the feasibility of the model and test the regression parameters simultaneously. On the results of the analysis of FEM model the value of Prob (F-statistics) of $0.000<0.05$ means that the model is feasible at a significance level of $5 \%$. It can be indicated that at least one independent variable has a significant effect on the dependent variable. Based on the results of $T$ test, all variables have a significant effect on $\mathrm{Y}$. The cost of distribution has a significant effect on the level of $5 \%$ with an estimated coefficient of 0.257 which means that a one percent increase in the variable cost of distribution will increase $Y$ by $0.257 \%$. Production costs have a significant effect on the level of $5 \%$ with an estimated coefficient of 0.255 , which means that if the production cost variable increases by one percent, $Y$ will increase by $0.255 \%$. Promotion costs have a significant effect on the level of $5 \%$ with an estimated coefficient of 0.189 , which means that an increase of one percent in the variable cost of promotion will increase $Y$ by $0.189 \%$. The R-Squared value was $99.78 \%$, meaning that $99.78 \%$ of the $\mathrm{Y}$ diversity was explained by the independent variable $(X)$ used while the remaining $0.22 \%$ was explained by other factors outside the model.

Interpretation of the Model Effect of Production Costs on Company Sales. Model analysis on consumer goods sector companies, t-statistic value shows that the production cost variable has a t-statistic probability of 0.0000 , which means the production cost variable has a positive influence on company sales because the t-statistical probability value is smaller than 0.05 (significance level of five percent). Production costs have a significant effect on the level of $5 \%$ with an estimated coefficient of 0.255 , meaning that if the production cost variable increases by one percent, sales will increase by $0.255 \%$.

Kotler's theory states that companies lower production costs with the aim of the company trying to set lower prices so that it can be more competitive in the market and increase sales. Production costs are needed to support the processing of raw materials into products that are ready to be marketed. Analyzing production costs is a way that can be done to determine the effectiveness and efficiency of production while maintaining product quality. One of the production costs is influenced by the effects of exchange rate fluctuations because some of the materials used in the production process are imported products.

Interpretation of the Model Effect of Promotion Costs on Company Sales. Model analysis on consumer goods sector companies, t-statistic value shows that promotion cost variable has a t-statistic probability of 0.0000 , this means that promotion cost variables have a significant influence on company sales because the t-statistical probability value is smaller than 0.05 (significance level of five percent). Promotion costs have a significant effect on the level of $5 \%$ with an estimated coefficient of 0.189 which means that if the variable promotion costs increase by one percent then sales will increase by $0.189 \%$. 
In companies in the consumer goods sector, the more promotion carried out the greater promotional costs incurred, sales of these companies will also increase. Companies engaged in the consumer goods sector include companies that are active in promoting in the mass media, for example advertisements with various versions on television. Marketing activities or promotions carried out by companies in the consumer goods sector are included in the promotion above the line. Media chosen indirectly about consumers, central management makes efforts to form the desired brand. The nature of promotions above the line is limited to audience acceptance.

Interpretation of the Model Effect of Distribution Costs on Company Sales. Model analysis on consumer goods sector companies, t-statistic value shows the distribution cost variable has a t-statistic probability of 0.0000 , this means that the distribution cost variable has a significant influence on company sales because the t-statistical probability value is smaller than 0.05 (significance level of five percent). Distribution costs have a significant effect on the level of $5 \%$ with an estimated coefficient of 0.257 , which means that if the production cost variable increases by one percent, sales will increase by $0.257 \%$.

The lack of distribution activities will affect the distribution costs. Companies in the consumer goods sector carry out a distribution strategy by creating an integrated distribution group. An extensive distribution network can ensure that the products that have been produced can be easily obtained by consumers. With this distribution group the company has access to reach outlets or retail in all regions of Indonesia. To further improve its service capabilities to be more efficient, it is necessary to increase the number of employees in various distribution areas.

\section{CONCLUSION}

The results of the analysis using the panel data regression equation using the FEM method, in the consumer goods sector, the variable cost of production, promotion costs, and distribution costs have a significant positive effect on the value of sales. Production costs must be controlled properly because they are directly in contact with the production process. By controlling production costs, the products produced can compete in the market because the cost of production is relatively lower so the company gets a profit. In addition, promotion costs also have a role in increasing the company's sales. promotional costs are incurred to carry out marketing activities such as advertisements, discounts, and prizes. Promotion also needs to be supported by good distribution channels to reach scattered consumers.

\section{RECOMMENDATIONS}

The variables in this study are production costs, promotion costs, distribution costs, and company's sales; the suggestion for further research is to add research variables such as selling prices and products produced in order to describe the company's overall sales.

\section{REFERENCES}

1. Anatan L, Ellitan L. 2008. Supply Chain Management, Teori and Aplikasi. Bandung (ID): Alfabeta.

2. Ardiyos. 2008. Kamus standar akuntansi. Jakarta (ID): Penerbit Citra Harta Prima.

3. Assauri S. 2009. Manajemen pemasaran konsep dasar and startegis. Jakarta (ID): Rajagrafindo.

4. Dunia FA. Abdullah W. Sasongko C. 2018. Akuntansi Biaya, Edisi empat. Jakarta (ID): Penerbit Salemba Empat.

5. Fachrodji A, Sumarwan U, Suhendang E, Harianto. 2009. Perbandingan dayasaing produk gondorukem di pasar internasional. Jurnal Manajemen and Agribisnis. 6(2): 140151.

6. Hansen, Mowen. 2006. Akuntansi Manajerial, edisi tujuh. Jakarta (ID): Penerbit Salemba Empat. 
7. Hermawan A. 2012. Komunikasi Pemasaran. Jakarta (ID): Erlangga.

8. Heviandri R, Sumarwan U, Retnaningsih. 2009. Analisis kepuasan konsumen terhadap layanan bandara soekarno hatta, serta implikasinya terhadap strategi pemasaran city check in terminal di Jakarta. Jurnal Manajemen and Agribisnis. 6(2): 124-139.

9. Kotler P. 2008. Manajemen Pemasaran, terjemahan Hendra Teguh. Jakarta (ID): Prenhalindo Pr.

10. Kotler P, Armstrong G. 1994. Dasar-dasar Pemasaran, terjemahan Wilhelmus WB. Jakarta (ID): Intermedia.

11. Kotler P, Keller KL. 2002. Manajemen Pemasaran. Jakarta (ID): Erlangga.

12. Manalu ASB, Sumarwan U, Suroso Al. 2007. Analisis faktor-faktor yang mempengaruhi kepuasan pelanggan online. Jurnal Manajemen and Agribisnis. 4(2):67-80.

13. Marwa S, Sumarwan U, Nurmalina R. 2014. Bauran pemasaran memengaruhi keputusan konsumen dalam pembelian asuransi jiwa individu. Jurnal IImu Keluarga \& Konsumen. 7(3):183-192.

14. Munawar A, Marpaung BS. 2008. Pengaruh biaya saluran distribusi terhadap tingkat volume penjualan pada PT. Winner Garments. Jurnal Ilmiah Kesatuan. 1(10): 13-19.

15. Mulyadi, 2001, Sistem Akuntansi. Edisi Ketiga, Cetakan Ketiga. Jakarta (ID): Penerbit Salemba Empat.

16. Nachrowi DN, Usman H. 2006. Pendekatan Populer and Praktis Ekonometrika untuk Analisis Ekonomi and Keuangan. Jakarta (ID): Lembaga Penerbit Fakultas Ekonomi Universitas Indonesia.

17. Nasution AH. 2003. Perencanaan and Pengendalian Produksi, edisi kedua. Surabaya (ID): Guna Widya.

18. Oktoriyana A, Sumarwan U, Hartoyo. 2014. Perumusan strategi pemasaran fry counter dengan pendekatan model AIDA. Jurnal Ilmu Keluarga \& Konsumen. 7(2): 103-112.

19. Rustami P, Kirya KI, Cipta W. 2014. Pengaruh Biaya Produksi, Biaya Promosi, and Volume Penjualan terhadap Laba pada Perusahaan Kopi Bubuk Banyuatis. E-Journal Bisma Universitas Pendidikan Ganesha Jurusan Manajemen. Vol 2.

20. Sari NP, Hapsari DW. 2015. Pengaruh Biaya Promosi and Biaya Distribusi Terhadap Penjualan (Studi Pada Perusahaan Sektor Food and Beverage yang Terdaftar di Bursa Efek Indonesia Periode 2009-2013). E-Proceeding of Management. 2(1): 472-478.

21. Savitri DA, Sumarwan U, Kurniawan DPY. 2014. dayasaing and model pemasaran sentra industri usaha kerajinan sangkar burung perkutut. Jurnal Manajemen and Agribisnis. 11(1): 24-32.

22. Swastha B, Irawan. 2008. Manajemen pemasaran modern. Yogyakarta (ID): Liberty.

23. Simamora H. 2002. Akuntansi Manajemen. Jakarta (ID): Salemba Empat.

24. Sugiyono. 2010. Metode penelitian pendidikan pendekatan kuantitatif, kualitatif and r\&d. Bandung (ID): Alfabeta

25. Sumarwan U. 2009. Pemasaran strategik, strategi untuk pertumbuhan perusahaan dalam penciptaan nilai bagi pemegang saham. Jakarta (ID): Inti Prima Promosindo.

26. Sumarwan U, Johan IR, Anindita D. 2011. Sikap, preferensi, and niat beli terhadap produk makanan ringan pada anak usia sekolah. Jurnal Ilmu Keluarga \& Konsumen. 4(1): 98-105.

27. Sumarwan U. 2012. Persepsi and preferensi iklan mempengaruhi niat beli anak pada produk makanan ringan. Jurnal Ilmu Keluarga \& Konsumen. 5(2): 185-192.

28. Sumarwan U, Noviandi A, Kirbrandoko. 2013. Analisis proses keputusan pembelian, persepsi, and sikap konsumen terhadap beras organik di Jabodetabek. Jurnal Pangan. 22(2): 19-35.

29. Swastha B. 2005. Management Pemasaran Modern. Ed Ke-12. Yogyakarta (ID): Liberty.

30. Wardani S. 2013. Analisis Pengaruh Biaya Produksi, Biaya Promosi, and Biaya Distribusi Terhadap Nilai Penjualan Pada Industri Barang Konsumsi [tesis]. Bogor (ID): Institut Pertanian Bogor.

31. Wardhani W, Sumarwan U, Yulianti LN. 2015. Pengaruh persepsi and preferensi konsumen terhadap keputusan terhadap keputusan konsumen hunian green product. Jurnal Manajemen and Organisasi. 6(1): 45-63. 